PART 1

Setting the Scene: History, State, and Law 
Laurence Roudart and Marcel Mazoyer - 9789004304758 Downloaded from Brill.come4/26/2023 04:38:28AM via free access 


\title{
Large-Scale Land Acquisitions: A Historical Perspective
}

\author{
Laurence Roudart and Marcel Mazoyer
}

\begin{abstract}
Large-scale land acquisitions have been a recurrent historical phenomenon since ancient times. This article analyses four of these historical processes: the latifundia of ancient Rome, enclosures in Britain, latifundia in the Spanish and Portuguese colonies of the Americas, and Soviet collectivisation. The article then compares these historical occurrences with the current wave of acquisitions in order to better understand the latter and to shed light on certain important debates in the areas of public policy and research that have once again come to the fore. Both the historical and current experiences share a set of economic and social characteristics: a small number of beneficiaries and a large number of dispossessed, exploitation of all or part of the land and the labour of those dispossessed of their land-some of them being excluded in certain cases - resistance, armed violence, laws favouring acquisitions, the decisive role of governments, and legitimising discourse. At the same time, the current wave of acquisitions has some specific characteristics of its own: its global scale, the context of public policy liberalisation, the facilitating role played by governments and international organisations, and the risk of wholesale exclusion. All of these features run counter to the main economic and social objectives of sustained development, namely, to reduce poverty, generate jobs and livelihoods for the greatest possible number, promote growth, ensure food security for all, and narrow income disparities.
\end{abstract}

\section{Introduction}

Following the surge in agricultural prices in 2007-2008, the increasingly frequent acquisitions of land rights, whether through purchase, lease, concession, or de facto occupation, has raised many questions. Can such a trend lead to the global expansion of wage-based, capitalist agriculture, and to what extent will this form of agriculture replace family holdings in developing countries, or indeed in developed countries? What are the potential economic, environmental, social, cultural, and political consequences of such upheavals?

(C) Graduate Institute of International and Development Studies, 2016 | DOI 10.1163/9789004304758_002 This is an open access chapter distributed under the terms of the Creative Commons Attribution- 
What might the effects be on production, employment, poverty, and food security?

Far from being a new movement or one unique to the capitalist system, the large-scale acquisition of vast areas for the benefit of their new owners, and to the detriment of previous rights holders and users who have been dispossessed of some or all of their rights, is in fact a recurrent event in history. Tombstone inscriptions and papyrus writings indicate that there were already large public estates under the Old Kingdom of Egypt during the third millennium $\mathrm{BC}$, where several villages were often obliged to provide unpaid labour to the state. Some of these estates were granted to the clergy or to officials of the royal court. Royal estates possibly existed even before the unification of Egypt and the establishment of the First Pharaonic Dynasty (Moreno García, 2008).

The first aim of this article is to analyse four historical instances of largescale land dispossession in order to single out their shared economic and social features. We have selected the following cases: the latifundia of the Roman Republic and Empire, as an experience of ancient colonisation that existed well before the development of capitalism; the enclosures in Britain, as an endogenous dynamic linked to the dissolution of the feudal regime and the emergence of capitalism; the large Spanish and Portuguese colonial estates in the Americas as a product of colonisation by external powers, which itself was linked to the expansion of mercantile capitalism; and collectivisation in the Union of Soviet Socialist Republics (USSR), as an endogenous dynamic linked to the wish to establish a sort of state capitalism within a managed economy. Our approach is fundamentally inductive in nature. It is aimed at bringing to the fore the traits common to historical experiences that each fall within a given economic and social dynamic. Nevertheless, this approach is also inspired by existing analytical frameworks, in particular concepts pertaining to agrarian political economy and the issues that this raises: who were the original possessors and users of land? What other social categories were concerned? What social relations existed between these various categories? Through what processes did these acquisitions and dispossessions of land take place? Were they sanctioned by legal and judicial mechanisms? Were they legitimised by a particular type of discourse? What social categories were involved in the newly-established production structures? What relations existed between them? What was being produced? Under what working conditions? How was the wealth thus created then distributed? For what purpose was it used? What were the consequences of these developments for the former users of the land? Did they become richer or poorer (Fairbairn et al., 2014; White et al., 2012; White and Dasgupta, 2010)? 
The second aim of this article is to analyse the current trend of acquisitions and dispossessions in the light of the common features identified from past experiences, so as to determine the extent to which the current trend is similar to or different from past instances of large-scale land acquisitions and thus shed light on a number of public policy and research issues that are currently being examined: what agricultural production structures are best suited to encouraging sustained human development-large-scale, wage-labour farm holdings or family-owned operations? What are the prospects for a political project based on an alternative conception of agricultural and general development?

Sections 2 to 6 of this chapter are each devoted to one of the four historical instances of land acquisition mentioned earlier, with Section 5 reviewing several others. Section 7 will present their common features. Section 8 analyses the current trend of large-scale acquisitions and dispossessions of land in the light of these common features while also pointing out their specific characteristics. Section 9 summarises the main findings of our analysis and correlates these with a number of important ongoing public policy and research debates.

\section{The latifundia of the Roman Republic and Empire}

In the fifth century BC, Rome was only a small republic whose peasant soldiers could barely hold out against attacks from neighbouring cities. By the end of the third century, a thoroughly battle-hardened Rome had already conquered the entire Italian peninsula, Sicily, Sardinia, Corsica and the southern part of Hispania. In the process, it had expropriated a large part of these territories, generally the best land, declaring it to be ager publicus - that is to say, agricultural land belonging to the Roman people. The Romans also confiscated mines, salt works, and the treasures of the conquered peoples, enslaving hundreds of thousands of prisoners of war.

Governed by its Senate, the Roman State rented out the greater part of this ager publicus in the form of large estates to rich individuals, most of whom were already landowners, senators or knights. As the state had fallen heavily into debt to support its wars and always needed further money to continue waging them, it sold whole sections of ager publicus at reduced rates or ceded full ownership by way of repayments. Roman property rights were individual, exclusive and fairly unrestricted. Large agricultural estates called latifundia were thus created, most often through the seizure of conquered land, which was leased out or sold as property (Nicolet, 1967). There came into existence a 
highly influential landed oligarchy, which put constant pressure on the state to make new conquests for the sake of increasing its wealth further.

Over the following centuries, thanks to military conquest, the ager publicus and latifundia greatly increased in area. Under the Empire, rich citizens started to occupy plots of ager publicus that had not been allocated by the state, initially upon payment of a modest amount of tax, and then without paying any tax at all as, over time, they came to regard themselves as owners of these plots. Large estate holders used other methods, legal or otherwise, to extend their holdings, by purchasing or usurping land belonging to peasants who had died in battle, who had been ruined, or who had given up farming, and by appropriating unregistered land and common pasture.

A single individual could control dozens, hundreds, or even thousands of hectares of land, perhaps divided into multiple different holdings of a few dozen or a few hundred hectares, which might be spread across different regions. Most owners of latifundia estates did not live on them, except occasionally for leisure purposes, and delegated the task of supervision to stewards. The necessary labour was generally provided by slaves or, failing that, by poorly-paid free peasants or by colonists, who were a category of tenant farmers allocated a plot of land in exchange for a share of their harvest, possibly reaching as much as two-thirds (Garnsey, 1988; Jones, 1974).

Over the course of various conquests, the extent of these colonial latifundia increased. As they were using very cheap land and labour, their grain, wine, and olive oil were shipped for sale at low prices in Rome and certain provincial cities, or to the military (CNRS, 1995). They gained market share at the expense of small and medium-sized holdings, which could not survive the competition. In the area around Rome, latifundia specialised in horticulture or extensive livestock breeding, the products of which faced less competition from imports (Aymard and Auboyer, 1995; Roux, 1910).

As a consequence, the Italian countryside became depopulated. A large number of peasants were at war or had been killed; many others, impoverished by the competition they faced, abandoned the land and became plebs in Rome. By the second century $\mathrm{BC}$, the recruitment of legionnaires from among the ranks of peasant landowners had declined significantly. The army was becoming professional, and Italy's food dependency on the provinces was becoming chronic (White, 1970).

In the first century $\mathrm{BC}$, several well-known Latin writers were sharply critical of the latifundia. In De Re Rustica, Varro admonished the absentee owners of large estates living idly in Rome and voiced concern regarding Italy's food dependency. In the Georgics, Virgil (1982) lyrically sang the praises of mixed-crop and livestock farming as practised by the owners of small farms, an increasingly rare breed. In the first century AD, in his Natural History (book 
XVIII ), Pliny the Elder felt that 'large estates have been the ruin of Italy, and are slowly proving to be the ruin of the provinces too', and reminded the reader that, " $[\mathrm{i}] \mathrm{n}$ old times it was thought that to observe moderation in the size of a farm was of primary importance, for the maxim was: sow less, plough better' (Pliny the Elder, 1848).

Yet at the start of the second century вС, an agrarian law had been passed with the aim of addressing this problem, by limiting the amount of ager publicus that could be leased to 125 hectares (500 jugera) per individual, capping the number of animals grazing there (100 head of large livestock, 500 head of small livestock), and placing an obligation on the tenants of large estates to employ a given proportion of free men rather than just slaves, all of which was enforceable by fines. However, this law was only very rarely applied and, in 133 вс, Tiberius Sempronius Gracchus, a Tribune of the Plebs, had a new agrarian law passed, which sought to return some urban plebs to the land, increase army recruitment, and restore the grandeur of Rome. This law was concerned exclusively with the ager publicus, rather than land held as property, which was not subject to any limitation. It confirmed the state's repossession of ager publicus above the maximum 125 hectares per person, permitting the ownership of an additional 62.5 hectares per male child, up to a limit of two children. In exchange, the holders of ager publicus obtained the land that remained to them as their full property. The land taken back by the state was supposed to be redistributed to poor citizens in 7.5 hectare lots, which was perceived as a truly revolutionary step. The law provoked strong opposition from senators and other owners of significant quantities of land, such that it sparked a civil war against the plebs who supported the law, and resulted in the assassination of Gracchus. Some years later, his brother Gaius picked up the baton of reform, and this set off a fresh wave of terror and massacres. Yet, despite this ferocious opposition, the law, as the expression of the people's will, was partly applied, albeit with numerous amendments. In particular, there was a growing tendency for plots of land to be allocated only in the provinces, and only to war veterans. The allocation of land to poor citizens would be resumed only under the consulship of Julius Caesar (Earl, 1963; Stockton, 1979).

These land allocations were however insufficient to stem the rural exodus and the swelling of Rome's plebeian population. By the early second century AD, the population of the city had reached about 1 million. As the food offered by the rich became less and less adequate to feed the poor, a whole series of wheat distribution laws, providing for the distribution of free or inexpensive grain to Roman citizens, were adopted (Duncan-Jones, 1974).

However, as the Empire slowly sank into a military and economic impasse because of the expansion of its frontiers, the growing strength of its external 
enemies, and the increasing number of domestic uprisings (by slaves and plebs), the Roman State no longer had the means to plunder new territories, with all their riches and their fresh manpower, by which it supported itself and its slave-based economy. Agricultural production collapsed on the Italian peninsula, despite numerous attempts by the state to remedy the situation (Finley, 1976).

During the highly-troubled times at the end of the Roman Empire, an increasing number of large landowners took refuge in their country villas. They organised by themselves the defence of their estates against attacks from disbanded legions, barbarians, and looters. They also arranged for their land to be farmed by a new kind of colonists, or serfs: these were former slaves, peasants, city dwellers or deserting soldiers, to whom the property owners allocated a plot of land in exchange for a share of the harvest and a significant amount of unpaid labour on the land they set aside for themselves (Bloch, 1947). This was the starting point for the gradual emergence of a new political, economic, and social order, which would take centuries to establish itself in the West, namely, feudalism.

As a result of the agricultural, food and health crisis of the fourteenth century, which culminated in the Black Death (1347-1350), Europe had lost around half its population. Land was once again plentiful but labour was in short supply (Mazoyer and Roudart, 2006). In early fifteenth century England, the feudal system found itself in difficulty. After two centuries of social conflict, the unpaid tasks that the serfs had to carry out on manorial land had become less arduous, and had been partly replaced by paid work, whose price was on the rise. Manorial estates had become difficult to manage. At the same time, a class of enriched serfs had come into being. They farmed more land on their own account, owned more livestock than others, and had control over the use of common pasture and forests. They even fulfilled certain judicial roles and helped maintain law and order. Given this situation, in the first half of the fifteenth century, almost all the landlords opted to lease their estates to these richer peasants, rather than to continue managing them by themselves (Byres, 2009).

The archetypal large structure of agricultural production that thus emerged would become the point of reference for the founding fathers of classical political economy (including Smith, Ricardo, Malthus, and Marx), in which the landlord rents out his land in exchange for payment of a land rent; the tenant farmer uses this land with the aim of turning a profit and pays this land rent; 
while agricultural labourers sell their labour to the tenant farmer in exchange for a wage.

Nevertheless, many peasant families who had been freed from serfdom continued to farm the plot of land to which they had been attached. Small and medium-sized farm holdings thus developed on the ruins of the feudal system, run by independent freeholders called yeomen, who cultivated their land on a more or less individual basis. They made use of common grazing rights on the fields after they had been harvested, and had access to common forests and pastures.

However, in the sixteenth century, the landlords formed alliances with their tenant farmers and began forcibly to take possession of common land as well as that being farmed by independent peasants. They demarcated the new boundaries of their estates, closing them off by means of hedges or low stone walls, hence the term enclosure given to this process of appropriation/dispossession. These appropriations grew in scale under the Protestant Reformation, when the royal authorities confiscated part of the estates of the Catholic Church, which until that time had been the largest landowner in the country, and granted this land to their clients, either free of charge or against payment. Many peasants were then driven out, and individual houses or even whole villages were razed to the ground. Many other peasants lost all or part of their access to common or individual land, and were therefore deprived of a large part of their livelihoods. A whole series of peasant revolts prompted the royal authorities to promulgate laws restricting these abusive practices. In the end, however, these laws had only a limited effect (Land, 1977).

Many of these newly-enlarged units specialised in raising sheep in response to the strong demand for wool from the rapidly-developing cloth manufacturing industries in Flanders and England. Sir Thomas More described the situation as follows: 'sheep, which are naturally mild, and easily kept in order may be said now to devour men and unpeople, not only villages, but towns, $[\ldots]$ there the nobility and gentry, and even those holy men [...] stop the course of agriculture, destroying houses and towns, reserving only the churches, and enclose grounds that they may lodge their sheep in them. [...] for when an insatiable wretch [...] resolves to enclose many thousand acres of ground, the owners, as well as tenants, are turned out of their possessions [...] are all forced to change their seats, not knowing whither to go; $[\ldots]$ what is left for them to do but either to steal, and so to be hanged (God knows how justly!), or to go about and beg and if they do this they are put in prison as idle vagabonds, while they would willingly work but can find none that will hire them; [...] One shepherd can look after a flock, which will stock an extent of ground that would require many hands if it were to be ploughed and reaped' (More, 1978). 
The policy of enclosure was pursued until the eighteenth and nineteenth centuries, and was furthered by a succession of Acts of Parliament, which sought to promote the first agricultural revolution of modern times by replacing fallow land with feed crops so as to increase livestock production, improve soil fertility, and boost crop production (Mazoyer and Roudart, 2006). These laws abolished common grazing rights, provided for common land to be shared and obliged owners to enclose their consolidated areas of land (Mingay, 2014; Slater, 1907). Though the application of the laws did not lead to dispossession everywhere (Hunt and Leuilliot, 1956), it undermined the economic position of those smallholders who lacked the means to enclose their land and lost their communal rights, to the extent that the worst off amongst them finally had to sell their land. As a result, whereas peasant land had still made up almost a third of agricultural land in England at the end of the seventeenth century, it accounted for only a fifth of it by the end of the nineteenth century (Beckett, 1999).

The enclosures caused many peasant holdings to disappear in favour of a small number of farming businesses employing only the minimum number of workers required to satisfy industrial and urban demand. This contributed to release many more unemployed onto the labour market than the number of jobs available in industry and in the cities. Therefore, enclosures were largely responsible for the development of a poor unemployed underclass in England, and more widely in Great Britain and the United Kingdom, which led the authorities to put in place a series of Poor Laws from 1536 to 1930 (Polanyi, 1971). According to E. Hobsbawm $(1977,188)$, 'the Poor Law of 1834 was designed to make life so intolerable for the rural paupers as to force them to migrate to any jobs that offered. [...] From 1850 land-flight became general'.

In Book One of Das Kapital, Karl Marx was already speaking about 'land grabbing' in relation to enclosures (Marx, 1965). He interpreted them as the founding event of the capitalist regime, prompting the formation of a class of individuals who owned the means of production, in this case land that had largely been stolen, and a class of footloose workers who had to sell their labour in order to survive, even if it meant working under the most unfavourable conditions.

Hoping for better times, many of the poor and unemployed emigrated to the settlements of North America, Australasia, and southern Africa, where vast territories were being seized by force from the native inhabitants. Enjoying access to vast lands that were usually cheaper than in the United Kingdom, and, from the nineteenth century onwards, being well-equipped with industrial machinery, these colonial farmers became more competitive than their European counterparts, to the extent that British industrialists, concerned to 
lower their costs of production as much as possible, concluded that it would be more beneficial for them if Britain imported agricultural produce at low prices (American wheat to feed the workers, Australian and New Zealand wool to supply the textile mills), rather than producing it locally. After much heated debate, they secured the repeal in 1846 of the protectionist grain legislation known as the Corn Laws (Schonhardt-Bailey, 2006), which led to the ruin of many British farmers. By an ironic twist of history, the landlords and tenant farmers had to concede defeat to those who were mostly descendants of the peasants that their ancestors had driven off their land at the time of the enclosures (Mazoyer and Roudart, 2006).

\section{$4 \quad$ Haciendas and Fazendas: Spanish and Portuguese Colonies in the Americas}

In January 1492, the armies of the Catholic Monarchs of Spain completed the reconquest of the Iberian Peninsula from the Muslims. A few months later, Christopher Columbus landed in the Bahamas, opening up the New World to the Spanish Crown.

The Spaniards who set out to conquer the Americas from this time onwards were mostly penniless nobles who had borrowed the necessary capital from merchants and bankers to fund their arms, travel to, and settlement in America, as well as the costs of the servants with which they surrounded themselves. There were also royal officials, soldiers, and clerics. In debt and greedy for profit, they began by pillaging the treasures of the defeated indigenous societies. Then, they set about exploiting the gold and silver mines. From the outset of the conquest, the royal authorities confiscated the conquered territories and distributed them as encomiendas - immense feudal fiefdoms- to expedition leaders, soldiers, royal officials and clerics, as well as compliant dignitaries from among the indigenous peoples. For example, Hernán Cortés, who defeated the Aztec Empire, received around four million hectares (Piel, 2013). These allocations usually applied for one or two generations. The encomenderos were responsible for exploiting the wealth of these fiefdoms while protecting, civilising, and evangelising the resident native populations. Taking advantage of what was in practice their absolute power, the encomenderos kept a large share of the best land for themselves, forcing the indigenous inhabitants onto marginal land. The encomenderos subjected them to largescale unpaid labour on their own estates, to forced labour in the mines, to deductions from their harvests in order to supply the towns and the mines, and to all sorts of ill-treatment or even massacres in response to any revolt. 
The consequences were disastrous. On the territory of the former Inca Empire, the indigenous population, which had been around 10 million in 1530, fell to 2.5 million in 1560 and to 1.4 million by 1590 , a level at which it remained unchanged until the early nineteenth century (Wachtel, 1977).

In response to the fervent denunciations of the encomienda system by clerics and royal officials, for both moral and economic reasons, the Crown undertook in the late sixteenth century gradually to replace this system with haciendas. These very large estates could cover several tens of thousands of hectares, with the hacendado enjoying sole ownership of the soil and the subsoil, as under ancient Roman law. This form of land tenure was a fundamentally alien notion to the native American societies, for whom possession of the land could only be collective.

A number of these haciendas were based on the old encomiendas, to which some territories purchased from the Spanish Crown had been added, while others were created from scratch, granted by the Crown for services rendered or sold, to conquistadors or compliant native chiefs. The Catholic Church, which benefited from large numbers of donations, became the biggest landowner. The fate of the indigenous populations was little different from before: they were confined to restricted areas, known as reducciones, where each family farmed its own plot and made use of common forests and pastures while being collectively subject to the payment of tribute to the haciendas, in labour or in kind (Kay, 1974). Tribute in kind was gradually replaced by taxation in cash, which obliged the farmers to work even harder for their sole employers, the hacendados, for a paltry wage. There were many revolts against these taxes and the endless expansion of the haciendas for the benefit of whites and mestizos (those of mixed race) to the detriment of the indigenous peoples, especially in the eighteenth century. These revolts were put down, however, and did not hinder the process (Luna, 2013).

Large-scale land grabbing also took place in Brazil, the vast territory that fell to the Portuguese Crown by the terms of the Treaty of Tordesillas (1494) between Spain and Portugal. Initially, the territory was divided into 15 hereditary captaincies allocated to nobles, who were responsible for exploring, exploiting, and administering them. The Portuguese Crown then conceded vast tracts of land, called seismarias, to individuals on long leases. Large plantations were set up, with a labour force consisting of slaves captured from amongst the indigenous populations, to produce sugar cane, cotton, coffee, cocoa beans, tobacco, etc. in function of the demand from Portugal and elsewhere in Europe. Over time, however, slave labour became scarcer and more expensive as the indigenous population had collapsed and survivors had fled to the interior or taken refuge in missions. Slaves then began to be imported 
from Africa to replace them, until the abolition of slavery towards the end of the nineteenth century. Thereafter, the masters of the large agricultural estates employed 'free' workers who were either ill-paid labourers, hired on a daily or seasonal basis, or tenant farmers or sharecroppers, often in debt to their masters and therefore at their mercy, or else resident former slaves who would be allotted a plot of land in exchange for their labour-effectively, they were a kind of serf (Bauer, 1979; Monbeig, 1984).

Independence was far from heralding an end to land grabbing. In the former Spanish colonies, constitutional decrees made changes to the conditions for accessing land, presenting new opportunities for setting up or enlarging haciendas. When the economic climate was favourable to exports (in 1850-1873 and 1890-1920, for example), the haciendas were further expanded, to the detriment of the indigenous peoples, either through the military conquest of new territories, with populations that resisted being exterminated, or by confiscating grazing land that had been declared to be surplus (Piel, 1988).

All in all, these large-scale land grabs gave rise to very significant transfers of wealth to Spain and Portugal, including to their respective Crowns. In addition, they formed the basis of the minifundia-latifundia land system that has endured in most countries of Latin America to this day, since subsequent agrarian reforms have in the main not been sufficient to supplant these dualist structures (Chonchol, 1970; Graziano Neto, 1991; Kay, 1998; 2014).

\section{Other Cases of Colonial and Postcolonial Dispossession}

Following the Age of Discovery, colonisation greatly accelerated, and took on different forms. Aside from the Spanish and Portuguese colonies in the Americas, it was above all in the colonies of settlement, set up in temperate zones, that land grabs at the expense of the native populations were most significant. These took place in the British colonies of North America, Australasia, and east and southern Africa; in the French colonies in North America and northern Africa; and in the Dutch colonies of South Africa. In different locations and at different periods, the indigenous people were either exterminated, driven out, or resettled in reserves, where the scarcity of good quality land forced them to work on the farms or plantations, or in the mines of the colonists (Bernstein, 2010).

In colonies of exploitation, the colonists exploited the land, the workforce, and other resources by forcing the indigenous populations to grow specific crops or to pay tax in cash, which obliged them either to produce and sell agricultural produce to be shipped to the home nation, or to carry out paid work in 
the mines or on the plantations. This was the case, for example, in the French colonies of sub-Saharan Africa, in the British colonies of South Asia and in the Dutch colonies of the East Indies (now Indonesia). At the same time, however, with the support of the colonial powers, vast tracts of land were also appropriated to be used by either companies or wealthy settlers to establish large plantations (of sugar cane, rubber trees, oil palms, cotton, bananas, tea, cloves, sisal, etc.) or to create areas for large-scale rice cultivation. These plantations developed most of all during periods of economic growth and expansion in international trade, especially following the two world wars (Bagchi, 2009; Beckford, 1999).

In sub-Saharan Africa, many newly independent states decided to nationalise their land, thus appropriating the rights to its use, in particular so that they could allocate vast tracts of land to be used for major agricultural projects by state or parastatal agencies, public or private companies, and even individuals. Millions of hectares were thus perfectly legally confiscated from local populations (Alden Wily, 2012).

6

Collectivisation in the USSR

In 1929, when the Communist Party decided to launch its collectivisation programme, the Russian peasantry still had memories of the terrible struggles for land and freedom that it had previously been compelled to wage.

To be sure, the Tsar had decided to abolish serfdom in 1861 and to redistribute some of the land owned by the nobility to peasant communities (mirs). This agrarian reform was rendered largely inoperative, but the idea itself became widespread at the end of the nineteenth century and after the Revolution of 1905. During the summer of 1917, after the Tsar had been deposed and many nobles had taken flight, peasants occupied their estates and undertook to distribute the land amongst themselves. After the Bolsheviks seized power, the decree on land of October 1917 endorsed this state of affairs, proclaiming the confiscation of large estates, and making them freely available to local agrarian committees (Méquet, 1930). In issuing this decree, Lenin and the Bolshevik Party, anxious to rally the peasantry to the revolution, conveniently shelved the ideas of nationalising all the land in the country and collectivising the large estates in order to set up model farms, as advocated in Lenin's April Theses and approved by the Bolshevik Party (Sorlin, 1964).

In 1921, to put an end to the peasant revolts and workers' strikes caused by the ambient economic chaos, the Bolshevik Party also agreed to adopt the more liberal 'New Economic Policy' (NEP). In 1928, however, to resolve problems with grain supply, the party launched the 'battle for grain'. Party emissaries 
were sent into the countryside to collect grain by whatever means necessary. This sparked a great many revolts, giving rise to fears that the first five-year plan of 1928-1932 might fail. To salvage the plan, and the revolution, a number of Politburo members, in particular Stalin, decided to implement a new policy, collectivisation, which came into effect in 1929 (Lewin, 1971).

The main objective of collectivisation was to oblige the peasantry to produce and deliver enough foodstuffs to supply the cities and permit the rapid industrialisation of the country (Nove and Morrison, 1982; Sapir, 1990). Furthermore, many Party members, inspired by Marx and Lenin, believed that family holdings were much less economically efficient than larger farms. But the official line went much further: according to Stalin (1930) it was imperative to 'eliminate the kulaks as a class', which meant that it 'must be deprived of the productive resources that make its existence and development possible (free use of land, ownership of the means of production, land-renting, right to hire labour, etc.).'

In a return to the Bolshevik Party programme of 1917, collectivisation involved nationalising all the land in the country, dissolving the mirs and replacing them with agricultural production cooperatives, or kolkhozes. The state made available land that had been nationalised, while villagers had to give over most of their means of production and pay to be admitted into the cooperative. Each family was meant to enjoy individual use of their dwelling, their vegetable garden, their gardening tools, and a small amount of livestock intended for domestic consumption (Stalin, 1930). Collectivisation also gave rise to the large state farms known as sovkhozes, along with machine and tractor stations that carried out work for the collective farms. In essence, the Soviet Union's land, workers, and farming activity were all controlled by the managers of the kolkhozes and sovkhozes, who were themselves under the orders of the Party.

Collectivisation got under way in the summer of 1929 and by March 1930 had already been applied to nearly 60 per cent of peasant families, or around 15 million families (Lewin, 1971). Supposedly voluntary, collectivisation was in fact imposed by force, often with acts of unheard-of violence being perpetrated by armed militia. There was mass destruction of livestock and agricultural equipment, both by peasants who refused to give them up to the kolkhozes and by the militias. The liquidation of the kulaks as a class' and of other opponents in general took the form of outright murder and mass deportation (Viola et al., 2005).

Fearing that this violence might eventually lead to failure, the Party's Central Committee allowed peasant families to leave the kolkhozes, which 9 million of them did in the spring of 1930, despite all the obstacles put in their way. This policy reversal did not last long, however, for in the autumn of 1930, 
collectivisation had resumed and would continue for nearly four years. By 1935, upwards of 9o per cent of agricultural land in the USSR was collectivised, with 4 per cent being set aside for family plots (Conquest, 1986).

Under Stalin, each kolkhoz was obliged to supply the state with large volumes of agricultural produce at low prices and to pay high taxes, either in cash or in kind. Agricultural labourers were organised into brigades. The pay for this work did not even cover the workers' basic needs, and the family plots only partly made up for the shortfall. The kolkhozniks lived in such deplorable conditions that many fled to the cities, leading the authorities to prohibit them from moving without formal permission (Danilov, 1988). With insufficient land for themselves, and now obliged to stay in their villages to work for almost nothing on large estates run by the state to supply industry and the cities, Russian peasants found themselves reduced to a situation of virtual state serfdom.

Common Characteristics

Although these past instances of large-scale land acquisitions are far removed from one another in both time and place, and are different in their social contexts and applications, they nonetheless share a set of common basic features.

Each of them benefited a very small number of individuals who, at little expense to themselves, became owners, tenants, de facto owners or stewards of large estates, whether the beneficiaries were foreign, like the Roman senators and knights, the Spanish hacendados or the Portuguese fazendeiros, or whether they originated from amongst the indigenous population, like the British landlords and tenant farmers or the Soviet hierarchs. These acquisitions were detrimental to a great number of previous rights holders and users of the land, who were completely or partially dispossessed of their land and livelihoods.

The beneficiaries were able to exploit not only the land, which was generally chosen from amongst the best available, but also, depending on the situation, all or part of the workforce formed by the dispossessed. In some cases, the dispossessors enlisted almost the entire workforce. In the Roman colonies, most of the able-bodied dispossessed were reduced to the condition of captive slave workers, or serfs paying a double tribute in the form of work and benefits in kind, or sharecroppers compelled to surrender a proportion of their harvest. In the Spanish and Portuguese colonies, they were reduced to being slaves or serfs, and then sharecroppers or small-scale tenant farmers or paid workers earning barely enough to live. In the Soviet Union at the time of collectivisation, dispossessed peasants became virtual state serfs. In other cases, 
the dispossessors employed only some of the labour of the dispossessed. At the time of the enclosures in Britain, landlords and tenant farmers employed only a fraction of those who had been dispossessed, as sharecroppers or agricultural labourers. Everyone else had to seek gruelling, low-paid employment, in the mines or in the burgeoning industrial sector, or had to settle for life as a vagabond or beggar, taking refuge in workhouses or poorhouses, or else emigrating to the colonies of settlement.

These large-scale acquisitions of land allowed a small number of dispossessors to derive unparalleled comparative advantages from their cheap land and workforce in responding to demand from more or less distant markets, or to orders from the state: wheat, wine and olive oil for Rome and its army; sugar, cotton, hides, meat, coffee, cocoa beans and tobacco for the European colonial powers; foodstuffs and raw materials for the expanding British cities and industries, and also for Soviet cities and industries under a regime of planned growth.

In every case, elements within the populations affected openly resisted the appropriation, and the consequent exploitation and marginalisation. There were instances of resistance to colonisation by 'barbarians' and native American populations, and there were escapes and revolts by slaves, serfs, and peasants who were maltreated or excluded, or who refused to accept collectivisation. All of these victims put up clandestine resistance to the domination of the oppressors on an everyday basis (Kerkvliet, 2009; Scott, 1987). Occasionally, these resistance movements managed to halt, locally and temporarily, and had the overall effect of slowing down the drive towards acquisition and dispossession. However, the lack of a broad alliance with the dispossessed of other regions and with other victims of the established order meant that the balance of power between the dispossesors and the dispossessed was not reversed and the acquisitions/dispossessions continued.

For the most part, land acquisitions were extended and perpetuated through the exercise of armed force that was greatly superior to that of the dispossessed: Roman, Spanish, and Portuguese armies; private militias imposing de facto the enclosures in sixteenth century Britain, or the seizures by Spanish and Portuguese conquerors; police forces applying the Enclosure Acts from the eighteenth century onwards; and-in Russia-Party militia, police, and the army imposing collectivisation. Those who resisted were pursued and killed as an example to others, or tortured before being put back to work, either in situ or in deportation camps.

Acquisitions were generally reinforced by an arsenal of formal legal and regulatory measures that established and protected the rights of the new possessors, without regard to the previous rights of the dispossessed. These statutory 
provisions either predated the appropriations - as was the case with Roman law for example - or they were imposed on an ad hoc basis, as was the case with the 'Indian Laws' of Spain, the Enclosure Acts, and the decrees on the nationalisation or collectivisation of agricultural land in the UsSR.

Furthermore, the beneficiaries developed a narrative to legitimise their actions: Rome's 'preventive' conquests to stave off supposed threats of attack (Castignani, 2012); the civilisation and evangelisation of indigenous peoples; the rational exploitation of resources and growth in productivity justifying the enclosures from the eighteenth century onwards; and the economic development and the construction of socialism during collectivisation in the UssR. At the same time, a derogatory discourse, depicting the dispossessed as inferior, developed: to the Romans they were uncivilised barbarians; to the Iberian conquistadors the Indians were inhuman savages; to the British nobles they were vile peasants; and to the Bolsheviks they were peasants with bourgeois aspirations.

Finally, by contributing to this discourse legitimising acquisitions of land rights, by adopting laws and regulations legalising these acquired land rights, and by the use of public force to impose and enforce these laws, states and governments, acting in concert with the beneficiaries, played a decisive role in these acquisitions (Lewin, 1971; Nicolet, 1967; Piel, 2013; Slater, 1907).

\section{Acquisitions Today}

Although the current wave of land acquisitions has given rise to a great many publications, the information that they convey is often unreliable and fragmentary (Scoones et al., 2013). They nevertheless allow us to consider that these current acquisitions share, in their own way, the general features described above, while differing from previous waves of acquisitions in terms of their context and some of their methods.

Their first particularity, from a geopolitical standpoint, is that such acquisitions are developing throughout the world, in virtual defiance of national borders, whereas they previously occurred in national or colonial territories that, while they might be vast, were under the control of a single state.

Since the 1980s, acquisitions have been greatly facilitated by the liberalisation of public policies. Indeed, the liberalisation of agricultural policies in developing countries, implemented as part of stabilisation and structural adjustment programmes, has deprived farmers of the technical, economic, and financial support that had enabled them to invest and progress, insofar 
as this support existed. Moreover, liberalisation in the international trade of agricultural produce, albeit incomplete, combined with the use of increasingly powerful and inexpensive methods of transportation and trade, has brought an ever-increasing number of farmers from all regions into competition with the world's most competitive agricultural producers, who in some cases receive subsidies from their governments. This has impoverished or ruined hundreds of millions of farmers (Mazoyer and Roudart, 2006). Finally, financial liberalisation has made it possible for major investors to enjoy easy access to cheap, large-scale credit.

Besides, the land policies implemented in many countries since the $1990 \mathrm{~s}$ have facilitated large-scale land acquisitions (Gironde and Senties Portilla, this volume) and have encouraged the concentration of land ownership rather than its redistribution (Borras Jr. and Franco, 2012). Governments and administrative authorities in the countries in which recent acquisitions have taken place play a considerable role, on the one hand by acting as intermediaries between national or foreign investors and local political authorities, and on the other by acquiring land themselves (Wolford et al., 2013). Meanwhile, some governments of the investors' countries of origin actively support these acquisitions (Woertz and Keulertz, this volume).

Another specific feature of the current wave of acquisitions is the major role played by international organisations. The International Monetary Fund (IMF), the World Bank, the Organisation for Economic Co-operation and Development (OECD), and the World Trade Organization (WTO) have greatly contributed to putting in place today's liberal economic rules. Furthermore, the Multilateral Investment Guarantee Agency (an agency of the World Bank) provides investors with guarantees against risks, while the World Bank and other development banks fund the infrastructures enabling such investments to become profitable. In addition, several international organisations have begun to draft non-binding principles to guide investors in their strategies (Borras Jr. and Franco, 2010).

Where land currently being acquired is effectively used for agricultural purposes, it is generally exploited by large, highly-capitalised farming units employing extremely productive mechanical, chemical, and biological means of production. These means are much more productive than those used by the vast majority of the world's farmers, most of whom work with manual tools and little or no agricultural inputs. The gap in productivity between the world's most productive and least productive farmers has never been as wide as it is today (Mazoyer and Roudart, 2006). It follows that production costs are far lower for the most productive farmers than for the others. And, within the 
current context of globalised trade, large, highly-capitalised farms are expanding over vast swathes of the globe and gaining increased market share to the detriment of many farmers in other regions.

The current wave of acquisitions and its consequences are therefore global in their implications. If it continued to grow, it could have a negative impact on hundreds of millions of individuals, either indirectly through competition on markets or directly through partial or complete dispossession. In today's world, land is an essential means of existence for many populations: when dispossessed, or excluded, they find themselves incapable of meeting their essential needs because they are surplus to labour requirements in other sectors of the economy (Li, 2011), without new continents available to colonise as a potential outlet. Over time, such a development would pose colossal political risks.

In order to combat these acquisitions, peasant organisations, some of which have an international outreach, have been engaging in campaigns of resistance. They are attempting to attract the attention of the press, public opinion, and political authorities, while mobilising other civil society organisations across the world (Borras Jr. et al., 2008; Edelman, 2003; McMichael, 2006). Some of these efforts have been successful: in 2009, the mobilisation against a project in Madagascar to lease more than one million hectares to the South Korean company Daewoo led to the resignation of the country's President and the abandonment of the project (Petric, 2011).

These particular features aside, the current wave of land acquisitions shares, in its own way, the characteristics common to past waves of acquisitions analysed above. Existing studies, although far from being exhaustive, show that these current acquisitions are of actual benefit to a small number of actors-a few thousand individual entrepreneurs, company shareholders, and managers or investors in public or private investment funds. In the meantime, on the ground, a great many individuals have already lost all or part of their livelihoods (Anseeuw et al., 2012; Gironde and Senties Portilla, this volume).

Just like the landlords and tenant farmers at the time of the enclosures, the new acquirers of land do not employ all the manpower offered by the dispossessed, partly because new holdings, when they are developed, are equipped with powerful machinery and require little labour $(\mathrm{Li}, 2011)$. It is also because a large portion of the newly-acquired land remains uncultivated (Land Matrix, 2014). In fact, many acquirers keep land in reserve, probably in anticipation of its increasing value or of a new surge in agricultural prices, or alternatively for reasons of environmental conservation. Others are slow to develop their land because of a wide range of technical, financial, and organisational difficulties (Boche, 2014).

The working conditions of labourers on large agricultural estates are usually very harsh. Permanent jobs are rare, while casual employment, of a daily or 
seasonal nature, is common. Working hours are variable and often unfair. Pay is often on a piecework basis, and is rarely adequate to cover the costs of supporting a family and even the labourer himself. Social security and accident prevention measures are practically non-existent (Hervieu and Purseigle, 2013; Hurst et al., 2005; IFAD, 2010; Jacques-Jouvenot and Laplante, 2009). Despite this, these jobs are sought after by the dispossessed, who are compelled to undertake any sort of casual work, legal or otherwise, or else end up as beggars or vagrants (Anseeuw et al., 2012). Being of no use to the economic or social system as either workers or consumers, these surplus populations are in practice excluded (Castells, 1998).

In fact, whenever investors develop newly acquired land, it is obviously to derive a profit by producing foodstuffs for which there exists a solvent demand. This corresponds to diverse, more or less distant markets (Borras Jr. and Franco, 2012), but the aim is not to satisfy non-commercial domestic needs.

Open acts of resistance by the dispossessed have taken place. As was the case in the past, they trigger a response from the forces of law and order, the army, paramilitary groups or private militias (Grajales, 2011). To forestall or stamp out such resistance, the dispossessors and the authorities resort to various forms of pressure including intimidation, threats, the withholding of information and the presenting of situations as faits accomplis. They claim that the transfer of land rights is necessary for the country's development, and equate any resistance with political opposition to the regime or the governing authorities (Cismas and Paramita, this volume; Jacob and Le Meur, 2010).

The neo-liberal-inspired legal and regulatory measures that have been put in place in many developing countries since the 1980 s (bilateral or multilateral investment treaties, and laws or codes governing investment and land) considerably benefit major acquirers of land rights, whereas the rights of the previous users, with no formal title that they can assert, are generally not taken into consideration (Alden Wily, 2012). In addition, the dispossessed have hardly any prospect of judicial redress (Golay, this volume). In this regard, the processes which formalise and commodify land rights have often had damaging effects on the poor (De Schutter, this volume).

The arguments of those who legitimise current land acquisitions emphasise what is considered to be the relatively unproductive, or even non-existent, use of the land in question, and the need to invest to increase agricultural production so as to feed a rapidly-growing human population and to supply biofuels, textile fibres, wood and other products. This discourse of legitimisation also asserts that 'large' farms (employing wage-earning manpower) are more productive than 'small' (family) farms, and that no significant progress can be expected from the latter (Collier, 2008). Finally, some new landowners claim to be acting in the name of environmental conservation (Fairhead et al., 2012). 


\section{Key Findings and Implications for Public Policy and Research Debates}

In the preceding pages, we have analysed the current wave of large-scale land acquisitions in the light of similar historical experiences. Given the limited space available, we have selected only four historical cases amongst many others. Our analysis is therefore incomplete and no claim is made here that the features identified as being common to these four cases would prove valid for all others. We nevertheless feel that this study permits a better understanding of current acquisitions and sheds light on the public policy and research debates that they have reopened.

One such debate concerns the structures of agricultural production and seeks to answer the following question: which production structures (familyowned farms or wage-based farms) are better capable of encouraging sustained development, primarily aimed at reducing poverty, generating jobs and livelihoods for hundreds of millions of people, promoting growth, providing food security for all and reducing income disparities while enhancing the environment (Byerlee et al., 2009; Thematic Group on Sustainable Agriculture and Food Systems, 2013)?

Our analysis shows that the current wave of acquisitions is driven, as were several past waves, by the search for cheap land and labour, for the purpose of creating large competitive units able to generate a profit by producing agricultural goods cheaply and by selling these goods to populations enjoying a degree of purchasing power. Like the previous waves, the current one is largely predicated on the dispossession of local populations, which directly impoverishes and excludes certain of their members. And, insofar as present land acquisitions are followed by the creation of large-scale, highly-equipped, productive and competitive farms, this current wave, like several previous waves, results indirectly in the impoverishment and exclusion of rural populations in other parts of the world through competition on the international market.

All of these effects run counter to the above-mentioned aims of sustained development.

Our analysis also suggests that the present acquisitions, promoted by many governments and major investors, reflect a broad consensus amongst the leading decision-makers, and that the negatively-affected social categories, and their various potential allies, appear unable to organise an effective political force putting up resistance and putting forward alternative proposals at the international, national, and sometimes local levels. Therefore, the current wave of large-scale land acquisitions leads researchers in the field of agrarian political economy to reflect on the parameters of an alternative agricultural 
development model to replace that which has held sway over the past few decades. Admittedly, this dominant model has created a great deal of wealth but it has also caused major environmental damage and much poverty and exclusion (McIntyre et al., 2009; MEA, 2005). And it has generated the current wave of large-scale land acquisitions, which leads researchers to consider also how an alternative agricultural development model could harness widespread political support.

\section{Conclusion}

On a planet where there is practically no more unused arable or grazing land left, it is more or less impossible to acquire the right to exploit large tracts of land without directly acting against the interests and living conditions of dispossessed rights holders and their descendants. And, in a global economy where solvent demand is already limited by enormous poverty, there are no more opportunities for large-scale investment in agriculture without indirectly reducing the market shares, incomes, or jobs of less competitive family farmers.

The current wave of large-scale land acquisitions, since it knows no boundaries, would, if it continued, have consequences on an unprecedented scale. Who would then house, feed and occupy the billions of people living in slums? Which authority would regulate the hundreds of millions of beggars, homeless people and migrants flocking towards those islands of prosperity that still remained? What army would contain the endless, pointless global civil war that would ensue?

Fortunately, however, we can never be certain that the worst will happen. At the beginning of the twentieth century, many democratic liberal governments concluded that large agricultural estates with paid workers were less conducive to economic development and social harmony than family farms, and accordingly adopted policies to further the development of the latter. And several of these governments even made agrarian reform the first step in their economic and social development policy. In the aftermath of the Second World War, the victorious liberal democracies, drawing lessons from the two major economic crises, totalitarian regimes, and two World Wars of the long preceding halfcentury, were anxious to provide full employment and an adequate level of well-being. They adopted policies to encourage widespread economic and social development, with close links between large-scale industry and family farming. They imposed agrarian reforms in several of the defeated countries, where the landed oligarchy had clearly been in league with the dictatorships. 
All of this with evident success! As the world attempts to steer a path towards sustained development on a global scale, it is a point worth remembering.

\section{References}

Alden Wily, L. (2012) 'Looking Back to See Forward: The Legal Niceties of Land Theft in Land Rushes', Journal of Peasant Studies, 39 (3-4), pp. 751-775, DOI: 10.1080/ 03066150.2012.674033.

Anseeuw, W., L. Alden Wily, L. Cotula and M. Taylor (2012) Land Rights and the Rush for Land: Findings of the Global Commercial Pressures on Land Research Project (Rome: International Land Coalition), http://www.landcoalition.org/sites/default/files/ publication/1205/ILC GSRreport_ENG.pdf (accessed on 4June 2015).

Aymard, A. and J. Auboyer (1995[1954]) Rome et son Empire (Paris: Presses Universitaires de France/Quadrige).

Bagchi, A.K. (2009) 'Nineteenth Century Imperialism and Structural Transformation in Colonized Countries' in Akram-Lodhi, A.H. and C. Kay (eds.) Peasants and Globalization: Political Economy, Rural Transformation and the Agrarian Question (London and New York: Routledge) pp. 83-110.

Bauer, A.J. (1979) 'Rural Workers in Spanish America: Problems of Peonage and Oppression', Hispanic American Historical Review, 59(1), pp. 34-63, DOI: 10.2307/ 2514135.

Beckett, J.V. (1999) 'La propriété foncière en Angleterre aux XVII ${ }^{\mathrm{e}}$ et XVIII ${ }^{\mathrm{e}}$ siècles', Histoire, Economie et Société, 18(1), pp. 25-41, http://www.persee.fr/web/revues/ home/prescript/article/hes_0752-5702_1999_num_18_1_2016 (accessed on 4 June 2015).

Beckford, G. (1999[1972]) Persistent Poverty: Underdevelopment in Plantation Economies of the Third World (Kingston, Jamaica: University of the West Indies Press).

Bernstein, H. (2010) Class Dynamics of Agrarian Change. Agrarian Change \& Peasant Studies (Sterling, va: Kumarian Press).

Bloch, M. (1947) 'Comment et pourquoi finit l'esclavage antique', Annales. Histoire, Sciences Sociales, 2(1), pp. 30-44, http://www.jstor.org/stable/27578330 (accessed on 4 June 2015).

Boche, M. (2014) Contrôle du foncier, agricultures d'entreprise et restructurations agraires: une perspective critique des investissements fonciers à grande échelle. Le cas de la partie centrale du Mozambique, unpublished PhD thesis (Paris: Université de ParisSud), https://tel.archives-ouvertes.fr/tel-01126967/ (accessed on 4 June 2015).

Borras Jr., S.M. and J.C. Franco (2012) 'Global Land Grabbing and Trajectories of Agrarian Change: A Preliminary Analysis', Journal of Agrarian Change, 12(1), pp. 34-59, DOI: 10.1111/j.1471-0366.2011.00339.x. 
(2010) 'From Threat to Opportunity? Problems with the Idea of a "Code of Conduct” for Land-Grabbing', Yale Human Rights and Development Law Journal, 13 , pp. 507-523.

Borras Jr., S.M., M. Edelman and C. Kay (2008) 'Transnational Agrarian Movements: Origins and Politics, Campaigns and Impact', Journal of Agrarian Change, 8(2-3), pp. 169-204, DOI: 10.1111/j.1471-0366.2008.00167.x.

Byerlee, D., A. De Janvry and E. Sadoulet (2009) 'Agriculture for Development: Toward a New Paradigm', Annual Review of Resource Economics, 1(1), pp. 15-31, DOI: 10.1146/ annurev.resource.050708.144239.

Byres, T.J. (2009) 'The Landlord Class, Peasant Differentiation, Class Struggle and the Transition to Capitalism: England, France and Prussia Compared', The Journal of Peasant Studies, 36(1), pp. 33-54, DOI: 10.1080/03066150902820453.

Castells, M. (1998) End of Millennium (Malden, MA: Wiley-Blackwell).

Castignani, H. (2012) 'Limpérialisme défensif existe-t-il? Sur la théorie romaine de la guerre juste et sa postérité', Raisons politiques, No. 45, pp. 35-57, DOI: 10.3917/ rai.045.0035.

CNRS (Centre national de la recherche scientifique) (1995) Du latifundium au latifondo: un héritage de Rome, une création médiévale ou moderne? (Paris: Centre Pierre Paris). Chonchol, J. (1970) 'Eight Fundamental Conditions of Agrarian Reform in Latin America', in Stavenhagen, R. (ed.) Agrarian Problems and Peasant Movements in Latin America (Garden City, NY: Doubleday), pp. 159-172.

Collier, P. (2008) 'The Politics of Hunger: How Illusion and Greed Fan the Food Crisis', Foreign Affairs, 87(6), pp. 67-79, http://www.jstor.org/stable/20699372 (accessed on 4 June 2015).

Conquest, R. (1986) The Harvest of Sorrow: Soviet Collectivization and the Terror-Famine (New York: Oxford University Press).

Danilov, V.P. (1988) Rural Russia under the New Regime (Bloomington: Indiana University Press).

Duncan-Jones, R. (1974) The Economy of the Roman Empire: Quantitative Studies (Cambridge: Cambridge University Press).

Earl, D.C. (1963) Tiberius Gracchus: A Study in Politics (Bruxelles: Latomus).

Edelman, M. (2003) 'Transnational Peasant and Farmer Movements and Networks', in Kaldor, M., H. Anheier and M. Glasius (eds.) Global Civil Society Yearbook 2003 (London: Sage), pp. 185-220.

Fairbairn, M., J. Fox, S.R. Isakson, M. Levien, N. Peluso, S. Razavi, I. Scoones and K. Sivaramakrishnan (2014) 'Introduction: New Directions in Agrarian Political Economy', Journal of Peasant Studies, 41(5), pp. 653-666, Dor: 10.1080/03066150. 2014.953490.

Fairhead, J., M. Leach and I. Scoones (2012) 'Green Grabbing: A New Appropriation of Nature?', Journal of Peasant Studies, 39(2), pp. 237-261, Dor: 10.1080/0306615o. 2012.671770. 
Finley, M.I. (ed.) (1976) Studies in Roman Property (Cambridge: Cambridge University Press).

Garnsey, P. (1988) Famine and Food Supply in the Graeco-Roman World: Responses to Risk and Crisis (Cambridge: Cambridge University Press).

Grajales, J. (2011) 'The Rifle and the Title: Paramilitary Violence, Land Grab and Land Control in Colombia', Journal of Peasant Studies, 38(4), pp. 771-792, DoI: 10.1080/03066150.2011.607701.

Graziano Neto, F. (1991) A tragédia da terra: o fracasso da reforma agrária no Brasil (São Paulo: IGLU-FUNEP-UNESP).

Hervieu, B. and F. Purseigle (2013) Sociologie des mondes agricoles (Paris: Armand Colin).

Hobsbawm, E.J. (1977[1962]) The Age of Revolution: Europe 1789-1848 (London: Abacus).

Hunt, H.G. and P. Leuilliot (1956) 'Vers une revision critique et statistique: aspects de la révolution agraire en Angleterre au XVIII ${ }^{\mathrm{e}}$ siècle', Annales. Histoire, Sciences Sociales, 11(1), pp. 29-41, http://www.jstor.org/stable/27579767 (accessed on 4 June 2015).

Hurst, P., P. Termine and M. Karl (2005) Agricultural Workers and Their Contribution to Sustainable Agriculture and Rural Development (Rome and Geneva: FAO-ILO-IUF), http://www.fao-ilo.org/fileadmin/user_upload/fao_ilo/pdf/engl_agricultureC4163. pdf (accessed on 4 June 2015).

IFAD (International Fund for Agricultural Development) (2010) Rural Poverty Report 2011 (Rome: IFAD), http://www.ifad.org/rpr2011/report/e/overview.pdf (accessed on 4 June 2015).

Jacob, J.P. and P.Y. Le Meur (2010) 'Introduction', in Jacob, J.P. and P.Y. Le Meur (eds.) Politique de la terre et de l'appartenance: droits fonciers et citoyenneté dans les sociétés du Sud (Paris: Karthala) pp. 5-57.

Jacques-Jouvenot, D. and J.J. Laplante (2009) Les maux de la terre: regards croisés sur la santé au travail en agriculture (La Tour-d'Aigues: Editions de l'Aube).

Jones, A.H.M. (1974) The Roman Economy: Studies in Ancient Economic and Administrative History (Oxford: Brunt P.A).

Kay, C. (2014) 'Rural Livelihoods and Peasant Futures', in Gwynne, R.N. and C. Kay (eds.) Latin America Transformed: Globalization and Modernity, 2nd ed. (London: Routledge) pp. 232-250.

(1998) 'Latin America's Agrarian Reform: Lights and Shadows', Journal of Land Reform, Land Settlement and Cooperatives (FAO), No. 2, pp. 8-31.

- (1974) 'Comparative Development of the European Manorial System and the Latin American Hacienda System', Journal of Peasant Studies, 2(1), pp. 69-98, DoI: 10.1080/03066157408437916.

Kerkvliet, B. (2009) 'Everyday Politics in Peasant Societies (and Ours)', Journal of Peasant Studies, 36(1), pp. 227-243, DOI: 10.1080/03066150902820487.

Land, S.K. (1977) Kett's Rebellion: The Norfolk Rising of 1549 (Ipswich, UK, and Totowa, NJ: Boydell Press-Rowman and Littlefield). 
Land Matrix (2014) Newsletter, various issues.

Lewin, M. (1971[1968]) Russian Peasants and Soviet Power (Evanston, IL, and London: Allen \& Unwin).

Li, T.M. (2011) 'Centering Labor in the Land Grab Debate', Journal of Peasant Studies, 38(2), pp. 281-298, DoI: 10.1080/03066150.2011.559009.

Luna, P.F. (2013) 'Latifundia, haciendas et landgrabbing, en perspective historique', HISTOIRE (S) de l'Amérique latine, 8, http://www.hisal.org/revue/article/Luna2013-8b (accessed on 4 June 2015).

Marx, K. (1965[1867]) 'Le Capital, livre premier', in Marx, K., CEuvres: 1, Economie (Paris: Gallimard).

Mazoyer, M. and L. Roudart (2006) A History of World Agriculture: From the Neolithic Age to the Current Crisis (London: Earthscan Publications).

McIntyre, B.D., H.R. Herren, J. Wakhungu and R.T. Watson (eds.) (2009) Agriculture at a Crossroads: Global Report (Washington, D.C.: International Assessment of Agricultural Knowledge, Science and Technology for Development), http://apps. unep.org/publications/pmtdocuments/Agriculture_at_a_Crossroads_Global_ Report.pdf (accessed on 4 June 2015).

McMichael, P. (2006) 'Reframing Development: Global Peasant Movements and the New Agrarian Question', Canadian Journal of Development Studies/Revue canadienne d'études du développement, 27(4), pp. 471-483, DOI: 10.1080/02255189. 2006.9669169.

MEA (Millennium Ecosystem Assessment) (2005) Ecosystems and Human Well-Being (Washington, D.c.: World Resources Institute), http://www.millenniumassessment. org/documents/document.356.aspx.pdf (accessed on 4 June 2015).

Méquet, G. (1930) 'Le problème agraire dans la Révolution russe', Annales d'histoire économique et sociale, 2(6), pp. 161-192, http://www.jstor.org/stable/27572184 (accessed on 4 June 2015).

Mingay, G.E. (2014[1997]) Parliamentary Enclosure in England: An Introduction to Its Causes, Incidence and Impact, 1750-1850 (London and New York: Routledge).

Monbeig, P. (1984) Pioneiros e fazendeiros de São Paulo (São Paulo: Hucitec).

More, T. (1978) L'Utopie de Thomas More (C edition, Bâle, 1518), edited by Prévost, A. (Paris: Mame).

Moreno García, J.C. (2008) 'Estates (Old Kingdom)', in Frood, E. and W. Wendrich (eds.) UCLA Encyclopedia of Egyptology (Los Angeles: University of California), https:// escholarship.org/uc/item/1b3342c2 (accessed on 4June 2015).

Nicolet, C. (1967) Les Gracques: crise agraire et révolution à Rome (Paris: Julliard).

Nove, A. and D. Morrison (1982) 'The Contribution of Agriculture to Accumulation in the 1930s', in Bettelheim, C. (ed.) L'industrialisation de l'URss dans les années trente (Paris: Editions de l'Ecole des hautes études en sciences sociales), pp. 47-64.

Petric, B. (2011) 'La ruée vers la terre', Transcontinentales, No. 10/11, http://trans continentales.revues.org/1060 (accessed on 4 June 2015). 
Piel, J. (2013) 'L'expropriation des terres et la formation du latifundium en Amérique espagnole et latine', HISTOIRE(S) de l'Amérique latine, 8, http://www.hisal.org/ revue/article/Piel2013-8 (accessed on 4 June 2015).

(1988) Capitalisme agraire au Pérou (Paris: Economica), http://books.openedition.org/ifea/1332 (accessed on 4 June 2015).

Pliny the Elder (1848) Histoire naturelle: Livre XVIII, traitant des céréales, edited by Littré, E. (Paris: Dubochet).

Polanyi, K. (1971[1944]) The Great Transformation: The Political and Economic Origins of Our Time (Boston: Beacon Press).

Roux, P. (1910) La question agraire en Italie: le latifundium romain (Paris: Félix Alcan). Sapir, J. (1990) L'économie mobilisée (Paris: La Découverte).

Schonhardt-Bailey, C. (2006) From the Corn Laws to Free Trade: Interests, Ideas, and Institutions in Historical Perspective (Cambridge, MA: The Mit Press).

Scoones, I., R. Hall, S.M. Borras Jr., B. White and W. Wolford (2013) 'The Politics of Evidence: Methodologies for Understanding the Global Land Rush', Journal of Peasant Studies, 40(3), pp. 469-483, DOI: 10.1080/03066150.2013.801341.

Scott, J.C. (1987) Weapons of the Weak: Everyday Forms of Peasant Resistance (New Haven: Yale University Press).

Slater, G. (1907) The English Peasantry and the Enclosure of Common Fields (London: A. Constable and Co.).

Sorlin, P. (1964) 'Lénine et le problème paysan en 1917', Annales. Histoire, Sciences Sociales, 19(2), pp. 250-280, http://www.jstor.org/stable/27576148 (accessed on 4 June 2015).

Stalin, J. (1930) La collectivisation du village (Paris: Bureau d'Editions).

Stockton, D. (1979) The Gracchi (Oxford and New York: Oxford University Press).

Thematic Group on Sustainable Agriculture and Food Systems (2013) Solutions for Sustainable Agriculture and Food Systems, Technical Report for the Post-2015 Development Agenda (New York: United Nations-Sustainable Development Solutions Network).

Viola, L., V.P. Danilov, N.A. Ivnitskii, D. Kozlov and S. Shabad (2005) The War against the Peasantry, 1927-1930: The Tragedy of the Soviet Countryside (New Haven, CT: Yale University Press).

Virgil (1982) Géorgiques, edited by de Saint-Denis, E. (Paris: Les Belles Lettres).

Wachtel, N. (1977) The Vision of the Vanquished: The Spanish Conquest of Peru through Indian Eyes, $1530-1570$ (New York: Barnes \& Noble).

White, B., S.M. Borras Jr., R. Hall, I. Scoones and W. Wolford (2012) 'The New Enclosures: Critical Perspectives on Corporate Land Deals', Journal of Peasant Studies, 39(3-4), pp. 619-647, DOI: 10.1080/03066150.2012.691879. 
White, B. and A. Dasgupta (2010) 'Agrofuels Capitalism: A View from Political Economy', Journal of Peasant Studies, 37(4), pp. 593-607, DoI: 10.1080/03066150.2010.512449. White, K.D. (1970) Roman Farming (Ithaca, NY: Cornell University Press).

Wolford, W., S.M. Borras Jr., R. Hall, I. Scoones and B. White (2013) 'Governing Global Land Deals: The Role of the State in the Rush for Land', Development and Change, 44(2), pp. 189-210, DOI:10.1111/dech.12017. 